\title{
SEKS PRANIKAH
}

\section{BAB I \\ PENDAHULUAN}

\section{- Latar belakang}

Di Indonesia, berbagai survei mengindikasikan bahwa praktik seks pranikah di kelangan remaja semakin merebak dan meluas. Kementrian kesehatan pada tahun 2009 merilis hasil studi tersebut, 35,9 persen remaja mengaku mempunyai teman yang sudah pernah melakukan hubungan seksual sebelum menikah. Bahkan survei PKBI (Perkumpulan Keluarga Berencana Indonesia) pada 2008, justru menyebutkan 63 persen remaja di beberapa kota besar telah melakukan seks pranikah (Jabodetabek 51\%; Bandung 54\%; Surabaya 47\%; dan medan 52\%). Hasil survei tersebut mengindikasikan kecenderungan bahwa seks pranikah telah menjadi bagian dari kehidupan remaja Indonesia.

Bagi masyarakat, perilaku tersebut dianggap sebagai 'pelanggaran atas norma/nila sosial'. Bahkan, sekitar 89 persen remaja sendiri - menurut survei Yayasan DKT, tidak menyetujui perilaku tersebut, meski faktanya 82 persen ramaja mengaku punya teman yang sudah melakukannya. Para remaja yang melakukan hubungan seks tidak menyadari akan akibat dari melakukan hal tersebut, misalnya terkena Penyakit Menular Seksual (PMS), HIV/AIDS, dan lain sebagainya.

Dari latar belakang tersebut dapat di rumuskan masalah yang ada, yaitu: apa itu hubungan seks pra-nikah, bentuk-bentuk seks pranikah, paktor penyebab yang menyebabkan ramaja melakukan hubungan seks pranikah, dampak negatif dari hubungan seks pranikah, bagaimana cara untuk mencegah seks-pranikah, tinjauan etika Kristen.

\section{- Tujuan Penulisan}

Manfaat dari penulisan makalah ini yaitu: mengetahui apa itu hubungan seks pranikah, mengetahui akibat-akibat dari hubungan seks pra-nikah, mengetahui cara menghindari hubungan seks pra-nikah. 


\section{BAB II \\ PEMBAHASAN}

\section{a. Pengertian Hubungan Seks Pra-nikah}

Seks pra-nikah secara umum dapat diartikan sebagai hubungan seks yang dilakukan ramaja sebelum menikah. Perilaku seks pra-nikah merupalan perilaku seks yang dilakukan tanpa memulai proses pernikahan yang resmi menurut hukum maupun menurut agama dan kepercayaan masing-masing individu. Pada seorang remaja, perilaku seks pra-nikah tersebut dapat dimotivasi oleh rasa sayang dan cinta dengan didominasi oleh perasaan kedekatan dan gairah yang tinggi terhadap pasanganny, tanpa disertai komitmen yang jelas (manurut Sternberg hal ini dinamakan romantica love); atau karena pengaruh kelompok (konformitas), dimana remaja tersebut ingin manjadi bagian dari kelompoknya dengan mengikuti norma-norma yang telah dianut oleh kelompoknya, dalam hal ini kelompoknya telah melakukan perilaku seks pranikah. ${ }^{1}$

Seks pra-nikah atau istilah kerennya "pre-marital sex" merupakan aktivitas seksual yang dilakukan tanpa adanya ikatan perkawinan yang sah. Pada umumnya, aktivitas demikian dilakukan oleh pasangan muda-mudi yang sedang asyik tenggelam dalam romantisme lautan asrama. Atau yang ingin menyalurkan hasrat seksual dengan orang lain selain pasangan kencan. Bentuk-bentuk aktivitas seksual pra-nikah yang dilakukan biasanya beragam. Mulai dari sekedar pegang tangan, berciuman, berangkulan, peting (saling menggesekkan kelamin), sampai yang paling mengkhawartikan yakni melkukan hubungan kelamin (sex intercourse). ${ }^{2}$

Seks pra-nikah adalah pembuktian dari rasa saling memiliki dan rasa sng dampak dari saling tulus mencintai dan itu hal yang dilarang agama. Pengetahuan informan tentang dampak dari perilaku seks pra-nikah yaitu cendrung, hamil diluar nikah, aborsi, merasa berdosa, putus sekolah, perempuan bisa kena kangker kandungan, penyakit spilis bagi laki-laki, raja singa, dan terjangkit HIV dan AIDS. ${ }^{3}$

\section{b. Bentuk-bentuk Seks Pra-nikah}

Bentuk-bentuk perilaku seksual pra-nikah pada remaja antara lain:

\footnotetext{
${ }^{1}$ Internet, http://zhoubie-prisos. Blogspot. Com/2010/05/seks-pranikah.

${ }^{2}$ Sidik Hasan \& Abu Nasma, Let's Talk abaut Love, (Solo: Tiga Serangkai, 2008), 29

${ }^{3}$ Internet, http://repository.unhas.ac.id/bitstream/handle/123456789/6167/jurnal\%20israwati.
} 


\section{- Berpelukan}

Perilaku seksual berpelukan akan membuat jantung berdegup lebih cepat dan menimbulkan rangsangan seksual pada individu atau pada pasangan tersebut.

- Cium Kering

Perilaku seksual cium kering berupa sentuhan pipi dengan pipi dan pipi dengan bibir. Dampak dari cium pipi bisa mengakibatkan imajinasi atau fantasi seksual menjadi berkembang disamping juga dapat menimbulkan keinginan untuk melanjutkan ke bentuk aktifitas seksual lainya yang lebih dapat dinimati.

\section{- Cium Basah}

Aktifitas cium basah berupa sentuhan bibir dengan bibir. Dampak dari cium bibir dapat menimbulkan sensasi seksual yang kuat dan menimbulkan dorongan seksual hingga tidak terkendali, dan apabila dilakukan terus menerus akan menimbulkan perasaan ingin mengulanginya lagi.

\section{- Meraba Bagian Tubuh Yang Sensitif}

Merupakan suatu kegiatan meraba atau memegang bagian tubuh yang sensitif seperti payudara, vagina dan penis. Dampak dari tersentuhnya bagian yang paling sensitif tersebut akan menimbulkan rangsangan seksual sehingga melemahkan kontrol diri dan akal sehat, akibatnya bisa melakukan aktifitas seksual selanjutnya seperti intercourse.

\section{- Petting}

Merupakan keseluruhan aktifitas seksual non intercourse (hingga menempelkan alat kelamin), dampak dari petting yaitu timbulnya ketagihan.

\section{- Oral Seksual}

Oral seksual pada laki-laki adalah ketika seseorang menggunakan bibir, mulut dan lidahnya pada penis dan sekitarnya, sedangkan pada wanita melibatkan bagian sekitar vulva yaitu labia, klitoris, dan bagian dalam vagina.

\section{- Intercource atau Bersenggama}

Merupakan aktifitas seksual dengan memasukan alat kelamin laki-laki dalam alat kelamin perempuan. ${ }^{4}$

\footnotetext{
${ }^{4}$ Internet, http://repository.usu.ac.id/bitstream/123456789/29728/4/Chapter\%20II.pdf
} 


\section{c. Faktor Yang Menyebabkan Remaja Melakukan Hubungan Seks Pra- nikah}

\section{- Faktor keluarga}

Faktor ini juga bisa menjadi penyebab terjadinya seks pra-nikah yang dilakukan oleh salah satu anggota keluarga tersebut, bisa terjadi pada anak, hal ini dikarenakan adanya permasalahan keluarga yang menimbulkan ketidak nyamanan didalam rumah dan ketidaknyamanan pada satu sama lain, sehingga menyebabkan kurangnya perhatian, ketidak perdulian atau kontrol atas prilaku dari anak sehingga anak mencari kenyamanan diluar tanpa adanya pihak yang mengikat atau pun kewajiban-kewajiban yang harus dipenuhi hanya mencari kepuasan semata. ${ }^{5}$

Dalam kondisi kesepian, merasa kurang diperhatikan orang tua, apa yang dilakukan anak? Dia akan makin menenggelamkan diri dalam dunianya sendiri. Menjadi pribadi yang tertutup, atau menyibukan diri dengan pergaulan diluar sana. Ayah dan ibu yang sama-sama bekerja. Anak akan lepas kendali, merasa bebas merdeka melakukan apa saja, bahkan menganggap kebebasan itu layak "dirayakan" karena ayah dan ibu sibuk sendiri diluar, tidak meperhatikan dirinya. ${ }^{6}$

\section{- Faktor Lingkungan}

Jika disuatu lingkungan yang sebagian besar oran-orangnya melakukan seks pranikah maka hal tersebut sedikit banyak mempengaruhi seseorang untuk ikut melakukan seks pra-nikah juga, karena secara sengaja atau tidak sengaja hal tersebut sudah menjadi bagian dikehidupan seseorang. Maka kemungkinan untuk melakukan seks pra-nikah semakin besar.

\section{- Faktor Ekonomi}

Faktor ekonomi termasuk faktor yang paling kuat atas terjadinya beberapa peristiwa yang bisa dikatakan melenceng dari norma-norma yang ada dimasyarakat, termasuk peristiwa seks pra-nikah ini, para pelaku seks pra-nikah melakukan hal ini untuk mencari nafkah menghidupi keluarganya yang berada dalam kondisi miskin atau pelaku tersebut melakukan seks pra-nikah untuk membiayai kehidupannya yang glamor, yang membutuhkan biaya hidup tinggi.

\footnotetext{
${ }^{5}$ Internet http://www.hukumpedia.com/hukum/5-faktor-penyebab-seks-pranikah

${ }^{6}$ Merry Magdalena, Melindungi Anak Dari Seks Bebas, (Jakarta:Grasindo, 2010),19-20
} 


\section{- Faktor Budaya}

Ada negara yang mempunyai budaya dimana masyarakatnya melakukan seks pra-nikah tanpa adanya norma-norma yang mempermasalahkannya, sehingga hal tersebut sudah biasa terjadi dikehidupan sehari-harinya.

\section{- Faktor Kurangnya Pendidikan Agama}

Kurangnya ajaran agama juga menjadi faktor yang menyebabkan terjadinya seks pra-nikah, karena mereka tidak terlalu mengetahui atau bahkan tidak mengetahui sama sekali, bahwa ajaran agama tidak menyarankan untuk melakukan seks sebelum manikah karena adanya sangsi dosa bagi yang meyakininya dan ada juga konsekuensi yang merugikan baik psikologi maupun material, jika didukung oleh pendidikan agama sedikit banyak sudah memiliki dasar keyakinan yang dapat mengurangi keinginan untuk melakukan seks pra-nikah, maka jika ingin melakukan hubungan seksual sebaliknya sudah menikah karena pernikahan didukung oleh hukum agama dan hukum negara yang legal sehingga dapat melindungi hak-haknya jika terjadi suatu hal yang merugikan. ${ }^{7}$

\section{d. Dampak Negatif Dari Hubungan Seks Pra-nikah}

Dampak negatif dari hubungan seks pra-nikah itu ada beberapa macam:

\section{Dampak Psikologis}

Dampak psikologis dari seks pra-nikah diantaranya perasaan marah, takut, cemas, depresi, rendah diri bersalah dan berdosa. ${ }^{8}$ Seks pra-nikah dapat menyebabkan, ketidakpercayaan, penyesalan, kekosongan diri. Seks menciptakan ikatan antara dua orang yang dapat dengan mudah dilanggar jika komitmen tidak cukup kuat untuk mempertahankannya.

\section{$>$ Dampak Fisiologis}

Dampak fisiologis seks pra-nikah tersebut diantaranya dapat menimbulkan kehamilan yang tidak diinginkan maka satu jalan yang diambil adalah aborsi. ${ }^{9}$

\section{Dampak Sosial}

\footnotetext{
${ }^{7}$ Internet http://www.hukumpedia.com/hukum/5-faktor-penyebab-seks-pranikah

${ }^{8}$ Internet,http://windanalurieta.wordprees.com/2013/03/06/perilaku-seks-pra-nikah-com

${ }^{9}$ Ibid., penyebab seks pra-nikah
} 
Dampak sosial yang timbul akibat perilaku seks yang dilakukan sebelum saatnya antara lain dikucilkan, putus sekolah pada remaja perempuan yang hamil, dan perubahan peran menjadi ibu. Belum lagi tekanan dari masyarakat yang mencalah dan menolak keadaan tersebut. ${ }^{10}$

\section{$>$ Dampak Fisik}

Penyakit menular seksual sering ditularkan ketika pasangan telah memiliki banyak pasangan seksual. Meskipun seks pra-nikah tidak selalu berarti pasangan memiliki beberapa mitra seksual, kemungkinannya lebih besar dari pada jika pasangan bersumpah untuk tidak melakukannya sampai menikah.

\section{Dampak Kehamilan}

Kehamilan menjadi kemungkinan, bahkan ketika menggunakan kontrasepsi. Menurut studi yang dilakukan pada tahun 2008, pasangan yang tinggal bersama sebagai suami istri sebelum menikah berada pada resiko perceraian yang meningkatkan resiko orang tua tunggal jika memiliki anak.

\section{$>$ Dampak perkawinan}

Sepasang suami istri juga bisa lebih mungkin mengalami masalah jika satu atau keduanya aktif secara seksual sebelum menikah. Pasangan dengan beberapa mitra seksual masa lalu mungkin menemukan diri mereka membandingkan kehidupan seks perkawinan mereka dengan kehidupan seks pra-nikah mereka, yang sering menimbulkan ketidakpuasan. Sebuah studi tahun 2002 juga menunjukan pasangan yang melakukan seks pra-nikah jauh lebih mungkin untuk bercerai dalam waktu 10 tahun dari pada mereka yang berpantang sampai pernikahan. ${ }^{11}$

\section{e. Cara Mencegah Seks Pra-nikah}

Mengapa seks pra-nikah perlu dicegah? Yang pertama adalah ketidaksesuaian dengan hal ini dengan budaya ketimuran dan nilai-nilai bangsa Indonesia. Alasan lain adalah seks pra-nikah sangat berpotensi memicunya kehamilan, penyakit seksual menular, aborsi, serta berbagai dampak negatif lainnya. Tanpa perlu berpanjang lebar lagi, berikut cara mencega seks pra-nikah antara lain:

\footnotetext{
${ }^{10}$ Ibid., perilaku seks pra-nikah

${ }^{11}$ Internet:http://www.academia.edu/6851210/Gambaran_Kecemasan_Remaja_yang_mengetahui_Akibat_Seks_Pra-nikah_dan_tetap_Melakukannya.
} 


\section{- Tanggung Jawab Orang Tua}

Sangat penting bagi para orang tua untuk meluangkan waktu dan mengajari anakanak tentang bagaimana sesunggunya seks yang sehat dan benar agar mereka tidak terpengaruh dengan cerita teman, buku-buku seks dan film porno yang beredar luas di pasaran. Memberikan informasi sekedar untuk menambah pengetahuannya, supaya si anak lebih mawas diri. Orang tua harus menjalin komunikasi yang baik dengan anak. Komunikasi yang baik tidak bisa dicapai dalam waktu sehari dua hari. Biasakan untuk ngobrol santai dengan anak, mulai dari hal yang ringan, jangan tunggu anak bertanya dan jangan limpahkan tanggung jawab pada orang lain. ${ }^{12}$ Orang tua harus memberikan pengertian kepada anak kalau tidak, anak-anak akan mencari informasi di luar, bahkan akan dihujani oleh informasi dari kawan-kawannya, dan tidak sulit untuk membayangkan, apa corak dan warna informasi itu.

Anak-anak biasanya bertanya terus terang dan orang tua jangan malu menjawab. Bila orang tua mengatakan, ini tidak usah kamu tahu, atau bahkan memarahi anak atau menolaknya mentah-mentah, pasti anak itu keheran-heranan dan ingin mencari tahu tanpa orang tua tahu. Maka mulailah suatu kerenggangan atau pemutusan hubungan dalam bidang yang sangat menentukan, yang seharusnya sama sekali tidak boleh dilepaskan dalam usaha mendidik anak.

Kewajiban orang tua untuk megikutsertakan anak-anak dalam bidang seks sejauh mereka dapat menangkap dan memahaminya. Bila orang tua terbuka, mereka pun terbuka, dan bilamana mereka menemui sesuatu masalah kelak, mereka akan berani mendatangi orang tuanya, karena jabatan kepercayaan sudah terpasang. ${ }^{13}$

\section{- Memberi Pendidikan Seks Yang Benar}

Pendidikan seks adalah langkah yang tidak boleh dilupakan dan merupakan salah satu cara mencegah seks pra-nikah paling penting. Ada banyak kasus dimana pergaulan bebas terjadi karena ketidaktahuan seseorang terhadap berbagai resiko seks luar nikah, seperti kehamilan, dan penyakit menular. Oleh karena itu, pastikan untuk memberi pendidikan seks pada anak-anak begitu mereka memasuki usia remaja.

\footnotetext{
${ }^{12}$ Alya Andika, Dari Mana Aku Lahir, cet pertama (Yogyakarta: Pustaka Grahatama, 2010), 108, $121-122$

${ }^{13}$ Volkhard \& Gerlinde Scheunemann, Hidup Sebelum \& Sesudah Nikah, (Batu-Malang: Yayasan Peresekutuan Pekabaran Injil Indonesia Departemen Literatur, 1978), 2-3
} 
Memang di Indonesia, pembicaraan tentang seks antara orang tua dan anak masih sering di anggap tabu. Namun seiring dengan berkembangnya zaman dimana informasi begitu melimpah dan mudah diakses, lebih baik memastikan bahwa anakanak mendapat informasi yang tepat langsung dari orang tua terutama untuk hal-hal yang bersifat krusial seperti seks diluar nikah.

\section{- Beraktivitas Positif}

Perilaku seks-pranikah terjadi karena terlalu banyak waktu yang dilewatkan dalam lingkungan yang tidak sehat. Oleh karena itu, untuk menceganya orang tua perlu mengisi hari-hari bersama anak-anak dengan hal-hal yang positif. Jangan biarkan terlalu banyak waktu yang kosong. Cobalah untuk mengajak anak supaya mengisi waktu-waktu tersebut dengan mengikuti kursus, belajar, atau menciptakan barbagai karya. Hal-hal positif tersebut membuat mereka sibuk sehingga tidak memiliki waktu untuk "keluyuran" dan "nongkrong" tidak jelas. Selain terhindari dari hal-hal buruk, aktivitas positif juga sangat bermanfaat untuk mengembangkan kepribadian seseorang ke arah yang lebih baik. ${ }^{14}$

\section{- Pikiran Masa Depan}

Pola pikir yang harus ditanamkan untuk mencagah anak untuk melakukan seks di luar nikah adalah dengan memikirkan masa depan. Bagi para remaja, poin ini harus di tanamkan dengan baik. Bayangkan nasib mereka jika ternyata sudah harus menjadi orang rua, padahal masih bersekolah dan belum mampu secara ekonomi. Ingatkan bahwa keluarga menaru harapan pada para remaja tersebut untuk menjadi orang sukses.

\section{- Menjalin Hubungan Akrab Antara Orang Tua Dan Anak}

Salah satu faktor penting yang sering dilupakan untuk mengurangi resiko seks di luar nikah adalah dengan cara menjaga hubungan baik orang tua dan anak. Anak yang kurang diperhatikan dan memiliki hubungan yang renggang dengan orang tua cendrung terjerumus ke perilaku seks pra-nikah. Begitu juga anak yang berasal dari keluarga yang tidak harmonis. Jika hubungan orang tua anak terjaga dengan baik, akan lebih mudah bagi anda untuk memantau dan mencagah sang anak masuk ke pergaulan

\footnotetext{
${ }^{14}$ Internet, http://www.top10indo.com/2013/07/10-cara-mencegah-seks-pranikah.html
} 
negatif. Jika orang tua perlu melakukan campurtangan dan menasehati sang anak, ia pun akan lebih mudah menerima dan menuruti nasihatnya. ${ }^{15}$

\section{- Memantau Prengaulan Anak}

Yang harus dipantau untuk mencegah seks diluar nikah adalah pergaulan. Perhatikan dengan siapa mereka bergaul. Perhatikan sikap teman-temannya, dan seberapa besar silapnya ikut berubah setelah bergaul dengan mereka. Jika anda menyadari perilaku negatif mulai muncul pada mereka, jangan ragu untuk langsung memberi nasehat. Pergaulan sangat berperan dalam mencegah seks diluar nikah. Jika para remaja masuk kedalam kalangan yang rajin belajar, taat, kemungkinan untuk terhindar dari pengaruh negatif. Oleh karena itu, jagalah baik-baik lingkungan pergaulannya.

\section{- Memilih Lingkungan Yang Positif}

Lingkungan sangat berperan dalam membentuk karakter serta perilaku keseharian kita jika kita ingin menjauhkan diri sendiri atau anak-anak dari seks pranikah, masuklah kedalam lingkungan yang kondusif. Pilihlah tempat belajar seperti kampus atau sekolah yang memiliki disiplin tertinggi, berperstasi, dan membina murid-muridnya untuk tidak hanya sekedar menjadi pandai, namun juga menjadi manusia yang baik. Oleh karena itu, pastikan untuk sebisa mungkin masuk ke lingkungan yang bagus.

\section{- Memberi Batasan Jam Malam}

Menurut penelitian sosiolog Universitas Cambridge, aktivitas seks pra-nikah $80 \%$ terjadi setelah jam 9 malam. Memang, jika memiliki kehudupan malam yang erat kaitannya dengan diskotik, klub bahkan prostitusi; seks pra-nikah sangat mungkin terjadi pada waktu-waktu tersebut. Apalagi di malam hari suasana jauh lebih sejuk, sehingga secara psikologis remaja menjadi lebih berani untuk mencoba hal-hal baru. Setelah memahami fenomena ini, cobalah untuk membatasi jam-jam malam para remaja. Jangan terlalu sering keluar malam, karena hal ini memperbesar kemungkinan terjadinya seks diluar nikah. Kehidupan malam juga erat kaitannya dengan kriminalitas, dan penyakit; oleh karena itu tidak ada ruginya dihindari.

- Pahami Dampak Negatif seks Pra-nikah

15 Ibid., 
Satu hal yang bisa membuat para remaja menjauhi seks pra-nikah adalah dengan memahami dampak negatifnya. Pahamilah bahwa seks diluar nikah bisa membawa konsekuensi yang sangat fatal bagi masa depan mereka, bahkan berujung kematian. Seks pra-nikah bisa meningkatkan resiko terjangkit AIDS, salah satu penyakit yang hingga saat ini belum ada obatnya. Selain itu secara psikologis seks diluar nikah juga membawa dampak yang buruk. Mereka akan seolah-olah dihantui oleh perasaan berdosa dan bersalah. Hal ini dalam jangka panjang bisa mengakibatkan turunnya rasa percaya diri, stres, bahkan depresi. ${ }^{16}$

\section{BAB III \\ TINJAUAN ETIKA KRISTEN}

\section{Pandangan Alkitab Terhadap Seks Pra-nikah}

Di dalam Alkitab kita dapat melihat bahwa kita sebagai umat kristen, kita harus tahu bahwa seks pra-nikah di larang dan tidak boleh dilakukan karena di dalam 10 hukum Allah yang tertulis, salah satu adalah "jangan berzina”. Ini menggambarkan bahwa kita tidak boleh melakukan seks pra-nikah (Kel 20:14). Kita harus mengajarkan anak-anak kita bahwa alasan Tuhan memberikan perintah Tuhan, adalah karena Dia ingin yang terbaik bagi kita. ${ }^{17}$ Seks pra-nikah bukan cara terbaik untuk dilakukan. Kita akan lebih bahagia dan dekat kehendak Allah dalam kehidupan kita jika kita menjaga hubungan seksual dalam hubungan janji pernikahan ${ }^{18}$

I Tesalonikah. 4:3 berkata inilah kehendak Allah: supaya saudara hidup suci menjauhi segalah hal yang cabul. Dalam beberapa versi Alkitab, itu diterjemahkan sebagai "hubungan seks diluar pernikahan". Hal ini terjadi dua orang berhubungan seksual dan mereka tidak terikat tali pernikahan. Firman itu kemudian berlanjut bahwa mereka harus tahu bagaimana menguasai tubuhnya. Kita dapat mengatakan kepada anak-anak supaya jangan melakukannya, tetapi tujuan yang lebih tingginya adalah untuk mengejarkan mereka mengapa dan bagaimana menjaga kekudusan seksual. ${ }^{19}$

\footnotetext{
${ }^{16}$ Internet, http://www.top10indo.com/2013/07/10-cara-mencegah-seks-pranikah.html

${ }^{17}$ Jim Burns, Teaching Your Children Healthy Sexuality, (Malang: PT. Visi Anugerah Indonesia, 2010), 38

${ }^{18}$ Anne K. Hershberger, Seksualitas Pemberian Allah, (Jakarta: BPK Gunung Mulia, 2008), 94

${ }^{19}$ Jim Burns, Teaching Your Children Healthy Sexuality..., 39-40
} 
Berikut ini ada beberapa fakta mengenai efek dari seks sebelum pernikahan yang di katakan oleh Jim Burns dalam bukunya yaitu:

Hubungan seks sebelum pernikahan cendrung menyebabkan putusnya hubungan pasangan; banyak pria yang tidak mau menikahi wanita yang telah melakukan hubungan seksual dengan orang lain; mereka yang telah melakukan hubungan seks sebelum pernikahan cendrung memiliki perkawinan yang kurang bahagia; pernikahan cendrung mereka yang telah melakukan hubungan seks sebelum pernikahan kemungkinan besar berakhir pada perceraian; orang-orang dan pasangan yang telah melakukan hubungan seks sebelum pernikahan juga cendrung untuk mempunyai affair di luar pernikahan; melakukan hubungan seks sebelum pernikahan dapat mengalabui anda untuk menikahi seseorang yang tidak tepat buat anda; orang-orang dan pasangan yang telah melakukan hubungan seks sebelum pernikahan lebih cepat mengalami kepuasan seks setelah mereka menikah; tetapi mereka kemungkinan menjadi kurang puas secara keseluruhan terhadap aktifitas seks mereka semasa pernikahan; kebiasaan buruk dalam hubungan seks sebelum pernikahan bisa membawa dan merusak seks dalam pernikahan. ${ }^{20}$

Didalam 1 Kor 6:19-20 bahwa ini adalah sebuah pesan mengenai apa dan bagaimana menjaga kekudusan seksual. Tugas kita adalah mengajarkan anak-anak kita untuk lari dari percabulan karena hal itu adalah tindakan yang benar dan murni. Pada ayat 19 mengatakan bahwa tubuh kita adalah tempat tinggal Roh Allah. Ini merupakan ilustrasi indah yang menggambarkan Roh Kudus menempati tubuh orang yang percaya. Fondasi yang kita bangun bagi anak-anak kita dan kita sendiri adalah menghormati tubuh kita, juga tubuh orang lain secara radikal. ${ }^{21}$

Sedangkan pada ayat 20 bahwa Firman ini terletak dasar kekudusan seksual. Firman ini mengingatkan kita bahwa pengorbanan Yesus memberikan kita kehidupan berlimpah di bumi dan disurga. Respons kita adalah mempersembahkan tubuh kita untuk-Nya. Tujuan setiap orang untuk membantu anak-anak mereka berkomitmen untuk kudus secara seksual. Bukan sekedar komitmen sekali waktu saja tetapi disiplin pribadi dan dalam kekudusan. ${ }^{22}$

Ikrar Kekudusan Seksual yang harus diterapkan didalam kehidupan para remaja untuk menghormati Allah, keluarga, dan calon pasangannya nanti. Maka mereka harus menyerahkan hidup mereka pada kekudusan seksual. Hal ini meliputi: Menghormati

\footnotetext{
${ }^{20}$ Jim Burns, Teaching Your Children Healthy Sexuality..., 42

${ }^{21}$ Ibid., 45

${ }^{22}$ Ibid., 46
} 
Allah dengan tubuh anda; memperbaharui pikiran mereka dengan hal-hal yang baik; memalingkan mata anda dari hal-hal yang tidak berguna menjaga hati anda di atas segalanya. $^{23}$

\section{BAB IV \\ PENUTUP}

\section{a. Kesimpulan}

Kesimpulan yang dapat kami ambil dari makalah ini adalah hindari hubunga seks pra-nikah jika masa depanmu ingin cemerlang. Karena, hubungan seks pra-nikah ini dapat menghancurkan masa depanmu serta memalukan keluargamu sendiri. Bahaya utama dari melakukan hubungan seks pra-nikah ini yaitu menderita penyakit HIV/AIDS yang sampai saat ini belum di temukan obat atau pencegahannya, banyak hal yang dapat dilakukan untuk menghindari hubungan seks pra-nikah. Hubungan seks pra-nikah ini dilarang keras oleh Tuhan. Untuk itu peren orang tua terhadap anak sangat dibutuhkan dalam memberikan pendidikan yang baik tentang seks kepada anakanaknya supaya mereka bisa menjaga kekudusan hidup mereka dihadapan Tuhan dan menjaga nama baik keluarganya.

\section{b. Saran}

Kelompok kami ingin memberitahukan dan menghimbau kepada pembaca terutama para remaja agar jangan sampai melakukan perbuatan seks pra-nikah. Karena kita adalah generesi penerus bangsa, tidak sepantasnya kita merusak masa depan kita dengan perilaku tidak bermoral seperti itu. Juga lebih baik kita mengisi waktu-waktu muda kita dengan melakukan hal-hal yang positif agar tidak menyesal di akhir nanti. Dan harus hidup takut akan Tuhan serta menjaga kekudusan hidup. Juga jangan lupa untuk selalu berdoa agar Tuhan selalu menolong kita.

\section{Soli Deo Gloria}

${ }^{23}$ Jim Burns, Teaching Your Children Healthy Sexuality..., 50 